\title{
ZSM5 as a Potential Catalyst for Glycerol Pyrolysis
}

\author{
Margarida L. Castelló1,2*, Jo Dweck¹, Donato A. G. Arandaํㅜ, Rosana C. L. Pereira ${ }^{3}$, \\ Manoel J. R. Guimarães Neto ${ }^{3}$ \\ ${ }^{1}$ Chemical School, Federal University of Rio de Janeiro, Rio de Janeiro, Brazil \\ ${ }^{2}$ Fluminense Federal Institute-Campus Macaé, Macaé, Brazil \\ ${ }^{3}$ Petrobras' Research Center, Rio de Janeiro, Brazil \\ Email: " margarida.castello@gmail.com, jodweck@yahoo.com.br, donato@gmail.com, \\ rosanacardoso@petrobras.com.br, manoel@petrobras.com.br
}

Received 9 December 2013; revised 8 January 2014; accepted 7 February 2014

Copyright (C) 2014 by authors and Scientific Research Publishing Inc.

This work is licensed under the Creative Commons Attribution International License (CC BY).

http://creativecommons.org/licenses/by/4.0/

(c) (i) Open Access

\begin{abstract}
Glycerol is a substance known to humankind for many years now, and among other products, in which composition it is used, are the pharmaceutical, cosmetic, food, paints and varnishes [1]-[6]. The abundance of its supply leads to search for new uses, whether as a plasticizer for biodegradable polymers [7], its transformation into other substances like propylene and derivatives or other hydrocarbons [8] [9], the production of hydrogen for energy purposes [10], or even direct burning, making glycerol a fuel for boilers, for example. The aim of this work was to investigate the action of the zeolite ZSM5 on glycerol fast pyrolysis at $600^{\circ} \mathrm{C}$. The tests were done with a mixture of glycerol-ZSM5 recently prepared using approximately equal volumes of glycerol and the catalyst, and the effluent gases from the fast pyrolysis have been analyzed in a chromatography/mass spectrometry (GC/MS) system. Experiments showed that ZSM5 acts in the pyrolysis of glycerol leading to a large number of substances, from oxygenated products to hydrocarbons, which are part of typical compositions of naphtha, diesel and gasoline petroleum derived products.
\end{abstract}

\section{Keywords}

Glycerol; ZSM5; Pyrolysis

\section{Introduction}

Glycerol is a polyalcohol, bearing a hydroxyl grouping in each of its three carbons. This gives it unique proper-

${ }^{*}$ Corresponding author. 
ties, since it presents facility in forming hydrogen bonds—strong intermolecular bonds—and justifies their melting and boiling points relatively high when compared to other substances of similar molecular weight [11] [12]. Similarly, intermolecular bonds with other hydroxyl bearing substances explain the miscibility with this kind of compounds, as are water and ethanol in which has infinite solubility [11]-[13]. In fact, the molecular char-acteristics of glycerol not only make it soluble in water, but also make it an extremely hygroscopic substance [7].

As an alcohol, glycerol can be reacted to form esters, ethers, halides, salts, amines, aldehydes and unsaturated compounds such as acrolein (2-propenal). It can also undergo oxidation reactions in only one hydroxyl, forming glyceraldehyde $\left(\mathrm{HOCH}_{2} \mathrm{CHOHCOH}\right)$ or dihydroxyketone $\left(\mathrm{HOCH}_{2} \mathrm{COCH}_{2} \mathrm{OH}\right)$. Glycerol can also polymerize and undergo some decomposition at $204^{\circ} \mathrm{C}$ [4], which means that distillation at atmospheric pressure is impractical. Industrially it is used vacuum distillation at a temperature of about $80^{\circ} \mathrm{C}$ [14].

Carmines and Gaworsky [15] studied the chemical composition of tobacco smoke with and without glycerol. This substance has been added in order to maintain the characteristics of tobacco, improving its moisture and providing an increase of flavor. However, doubts about the production of acrolein during the burning cigarette led the authors to investigate the behavior of glycerin when heated from room temperature to $1000^{\circ} \mathrm{C}$ in three stages: $400^{\circ} \mathrm{C}$ for $10 \mathrm{~s}, 700^{\circ} \mathrm{C}$ for $10 \mathrm{~s}$, and $1000^{\circ} \mathrm{C}$ for $10 \mathrm{~s}$. The products were condensed at $-196^{\circ} \mathrm{C}$ and analyzed by gas chromatography. The result showed that very little glycerol undergoes pyrolysis under these conditions, remaining intact. The test was repeated in air for determination of oxidation products. The results also showed that the major part of glycerol has not suffered reactions, but a very little amount of acrolein and glyceraldehyde have been detected in the smoke.

The potential use of glycerol in the production of plastics precursor monomers led to more accurate studies of hydrogenolysis, acrolein dehydration and oxidation (including synthesis gas production). Mota, Silva, and Gonçalves [16] discuss the chemical transformation of glycerol into ethers and esters of great technological applications, especially in the fuel sector. They also considered transformations into epichlorohydrin (1-chloro 2,3-epoxypropane) and glycerol carbonate (1-hydroxymethyl 1,3-dioxalan 2-one) because of the economic relevance of these products. Due to a large tree of products, the word "glicerochemistry" appears in the paper, quite appropriately to refer to the variety of products that can be obtained from glycerol. Glycerine (as it is called the commercial solution of glycerol with approximately 95\% purity) is produced at a rate of $100 \mathrm{~kg}$ for each 1 thousand liters of biodiesel, which means a growing supply of this trialcohol in the coming years. Although they have been investigated by the authors technological routes that require high pressures (about 45 $\mathrm{MPa}$ ) and low temperatures (around $300^{\circ} \mathrm{C}$ ), it seems promising searching for catalysts able to convert glycerol into high-value products for technologies energetically and economically favorable.

Kim, Jung, and Park [17] studied the dehydration of glycerol on silica-alumina catalysts with different Si/Al molar ratio (SAR). The initial conversion of glycerol at $315^{\circ} \mathrm{C}$ is extremely dependent on the total amount of acid sites in the silica-alumina catalysts. The production of acrolein was proportional to the concentration of the Brönsted acid sites, whereas the hydroxyacetone was produced in the proportion of Lewis acid sites. The authors argue that the coke deposition in stronger acid sites was the primary cause of catalyst deactivation. Research suggests that solid mesoporous acid catalysts with moderate Brönsted acid sites may be good candidates for producing acrolein as well as to a stable glycerol conversion.

The thermal degradation of glycerol can lead to a large number of substances, depending on the catalysts choses for the process. Suprum, Lutecki, and Papp [18] [19] tested the performance of bifunctional catalysts MOx- $\mathrm{Al}_{2} \mathrm{O}_{3}-\mathrm{PO}_{4}$ (containing different acid sites and different oxides of transition metals (M)) in the degradation of glycerol. The higher the acidity, the higher the selectivity for acrolein in the following order: $\mathrm{W}, \mathrm{Mo}, \mathrm{Cu}, \mathrm{V}$, $\mathrm{Fe}, \mathrm{Cr}$, Ce. Moreover, catalysts containing $\mathrm{Mn}, \mathrm{Cr}$ and $\mathrm{Fe}$ favor the formation of oxidation products with breakage of the $\mathrm{C}-\mathrm{C}$ bonds. The main reaction products were acrolein and acetol (hydroxyacetone). In lesser amounts were detected acetaldehyde, propionaldehyde, allyl alcohol, acrylic acid, propionic acid, acetone, carbon monoxide, carbon dioxide, phenol and other cyclic compounds C6. Finally the authors conclude that, under the conditions described and considering the results of all catalysts tested, preponderates the formation of acrolein and acetol between $220^{\circ} \mathrm{C}$ and $300^{\circ} \mathrm{C}$, reaching a maximum at $240^{\circ} \mathrm{C}$.

Thermal analysis showed that glycerol has a good thermal stability, even in air [20]. When heated with 10, 15 and $20^{\circ} \mathrm{C} \cdot \mathrm{min}^{-1}$ constant heating rates from $30^{\circ} \mathrm{C}$ to $600^{\circ} \mathrm{C}$, on $100 \mathrm{~mL} \cdot \mathrm{min}^{-1}$ flow of nitrogen, glycerol does not undergo only to a volatilization, but this is the predominant process in the range of $10 \%-40 \%$ conversion. By comparing the activation energy calculated by Kissinger and Osawa-Flynn-Wall methods, it was concluded that 
with the increasing degree of conversion, it also increases the activation energy of the overall process, which suggests the occurrence of chemical reactions. Confirmation of these findings occurred by using another methodBlazejowsky - that allows the calculations of enthalpies of volatilization based on Van't Hoff equations [21].

Zeolites are hydrated aluminosilicates of crystalline structure which have laminar, fibrous cavities with nanometric dimensions, interconnected or not, in which they lodge ions, molecules, or salts [22]. The connections between the pores allows a mass transit limited only by the dimensions of these cavities, which can vary widely across zeolites, but favoring the contact between the reagents and leading to chemical reactions. The large volume of pore in zeolites makes these catalysts very useful in petroleum refining industries, providing the cracking of large molecular weight molecules. The ZSM5 (Zeolite Socony Mobil 5) has some characteristics, such as its peculiar morphology of pores. This zeolite (also called "pentasil" by its crystalline structure that resembles three-dimensional mosaic forming pentagons) has two systems of elliptical channels which intersect each other, one straight and other sinusoidal, where bind the openings of $10 \mathrm{MR}$ (8 rings formed by pentagons and two hexagons. $\mathrm{Al}$ or $\mathrm{Si}$ forms the vertices, and oxygen connects chains rings. The typical pore size is between 5.4

and 5.6 $\AA$, the crystallographic unit cell has 96 sites ( $\mathrm{Si}$ or $\mathrm{Al}$ ), the 196 sites of oxygen, and the number of compensation cations dependent on the $\mathrm{Si} / \mathrm{Al}$ ratio (SAR) varying greatly from 12 . These are sites at which compensation cations have a protonic charge, which give the ZSM5 the acidity needed for the breaking of the C-C bonds [23]. In this paper are reported experiments that indicate use of ZSM5 as a potential catalyst for glycerol transformation.

\section{Experimental}

For the experiments, the authors used pro analysis glycerol from Proquímicos. The zeolite used was ZSM5 from Sentex with the following technical specification: relationship silica/alumina ratio (SAR) 25.0 to 29.0; pore volume from 0.110 to $0.140 \mathrm{~cm}^{3} \cdot \mathrm{g}^{-1}$; specific area $350-370 \mathrm{~m}^{2} \cdot \mathrm{g}^{-1}$; ground with average particle size 1.7 to 3.0 microns; typical concentration of $\mathrm{SiO}_{2} 94 \% \mathrm{~m} / \mathrm{m}$ and of $\mathrm{Al}_{2} \mathrm{O}_{3} 5.9 \% \mathrm{~m} / \mathrm{m}$. Before the tests, the zeolite was heated for $4 \mathrm{~h}$ hours at $500^{\circ} \mathrm{C}$. Afterwards, similar volumetric quantities of glycerol and ZSM5 were mixed up in an Eppendorf tube and vigorously shaken. The Eppendorf tube has been chosen due to its chemical stability, perfect sealing (which prevents the water absorption), and because the mixture did not significantly change its temperature. The resultant mixture was very viscous. For the experiments, little quantities of the mixture were taken with a metallic needle and carefully transferred to the CDS Pyroprobe ${ }^{\circledR}$ Model 5000 quartz holders. The same mixture has been tested three times, always under the same conditions, in the same pyrolyser, but using three quartz sample holders.

During the analysis platinum filaments are rapidly heated for pulse pyrolysis work, controlled for programmed analyses. The analytical runs have been programmed for one single step per sample, with automatic control of the on-line valve, interface temperature, GC ready sensing and GC start. Simple PC control of all parameters was used, permitting method development, storage, notation and editing. The effluent gases from the fast pyrolysis have been analyzed in a chromatography/mass spectrometry (GC/MS) system.

The analytical runs have been made under the following method: initial temperature $150^{\circ} \mathrm{C}$ for 20 seconds, followed by rapidly heating to $600^{\circ} \mathrm{C}$ (at a rate of $800^{\circ} \mathrm{C} \cdot \mathrm{s}^{-1}$ ), with $\mathrm{He} 1 \mathrm{~mL} \cdot \mathrm{min}^{-1}$ as carrier gas. The transfer line and the oven valve to chromatograph were both at $280^{\circ} \mathrm{C}$. The chromatograph was the Agilent Technologies GC 6890N model. The column was a 30 meter DB5 model of JW (methyl silicone with 5\% phenyl-methyl silicone), medium polarity, had $0.25 \mathrm{~mm}$ internal diameter, and the inner film was 0.25 micron. Before the analysis, the column was cleaned from possible impurities for 20 minutes at $300^{\circ} \mathrm{C}$ with He in a flow of $3 \mathrm{~mL} \cdot \mathrm{min}^{-1}$. For the analysis runs, the chosen temperature program leave the column for $10 \mathrm{~min}$ at $40^{\circ} \mathrm{C}$ followed by heating up to $280^{\circ} \mathrm{C}$ in a $30 \mathrm{~min}$ ramp, and remained at this temperature for $10 \mathrm{~min}$. The carrier gas was $\mathrm{He}$ at $1 \mathrm{~mL} \cdot \mathrm{min}^{-1}$ and the transfer line to MS was also maintained at $280^{\circ} \mathrm{C}$. The mass spectrometer was the Agilent Techlologies model 5973N, operating under the standard tune method. The carrier gas was He at a flow rate of $1 \mathrm{~mL} \cdot \mathrm{min}^{-1}$, at a pressure of $1.8 \times 10^{-5}$ torr.

\section{Results and Discussion}

The analytical runs have been done three times, but the results shown in this paper are not a medium value. In order to give a better idea of the tests, the authors picked one up and used it as an example of the behavior of glycerol under fast pyrolysis. Analyses of the effluent gases from the pyrolysis system showed that in fast pyro- 
lysis at $600^{\circ} \mathrm{C}$ pure glycerol suffers little conversion. In other words, most of the sample was just volatilized. This same behavior is predominant in the presence of ZSM5, but there is also the production of a large variety of organic compounds in small quantities (Figure 1).

In the first part of the spectrum there is a strong coelution, indicating that there was a formation of many compounds of low mass, whose separation was not efficiently accomplished by the chromatography. However, for purposes of preliminary observation, Figure 2 shows details of the analysis outset ( $3.5 \mathrm{~min}$ ), where it is possible to detect compounds as propenal (acrolein), acetaldehyde, ethylene oxide and propanol.

At the end of the chromatographic analysis other compounds have been identified, in general oxygenated compounds or olefinic and aromatic hydrocarbons (two or more double bonds), as shown in Figure 3.

The peaks labeled by numbers are those with unambiguously positive identification. Those labeled by letters are oxygenates compounds whose identification was not possible within the parameters established in the methodology used in this study (Table 1).

\section{Conclusions}

- The ZSM5 is able to change significantly the thermal decomposition of glycerol.

- Even during pyrolysis, when the heating rate is so fast that it does not favor the occurrence of reactions, the ZSM5 has been capable to promote the formation of a large number of different substances.

- Some of the compounds formed are part of typical composition for gasoline, while others could be included in the diesel pool.

- The results show that the ZSM5 can be an interesting catalyst in pyrolysis processes of glycerol, meaning further studies are highly recommended.

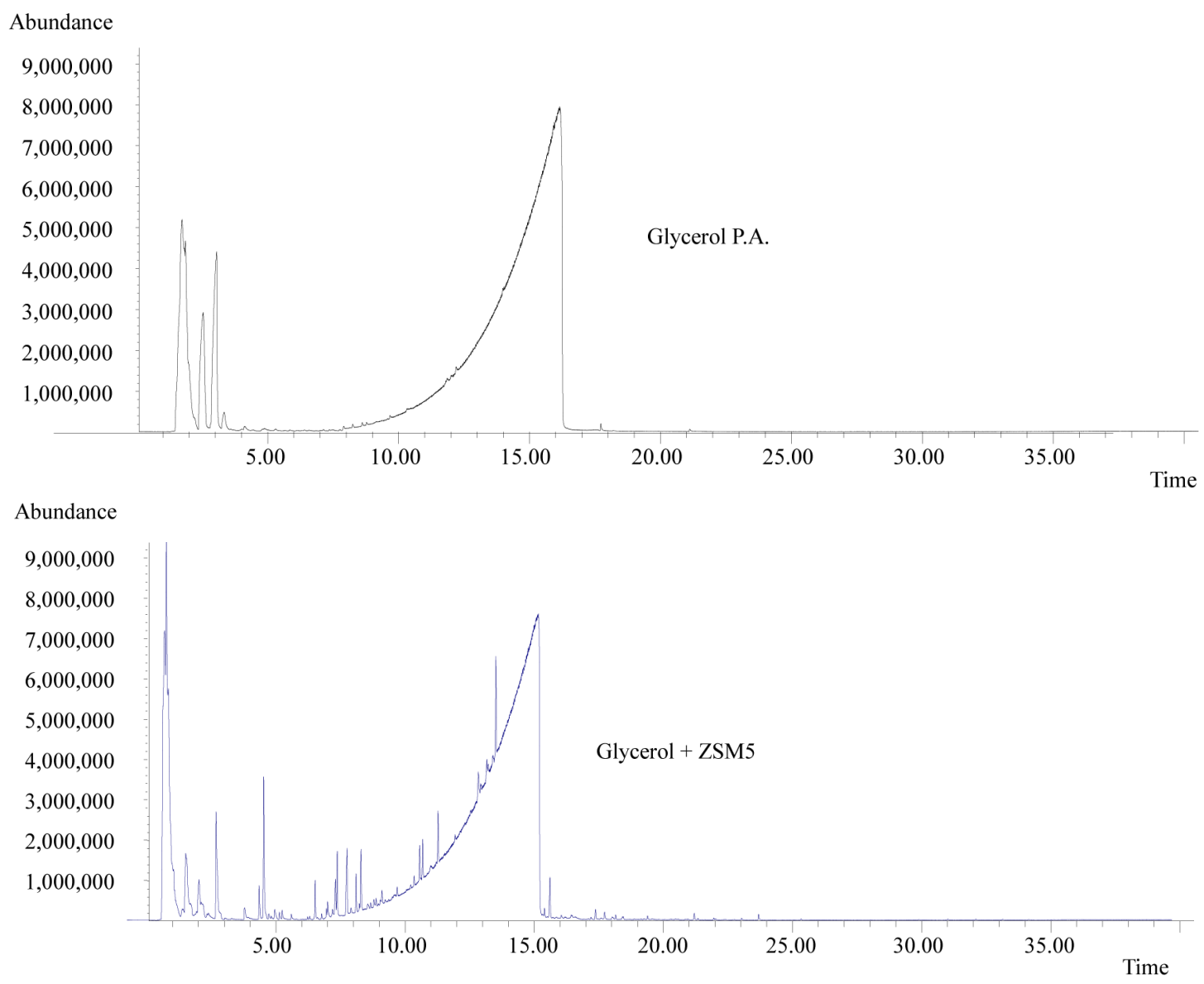

Figure 1. Mass spectra of pure glycerol (top) and a 1:1 mixture of glycerol-ZSM5 (bottom) after fast pyrolysis at $600^{\circ} \mathrm{C}$. 


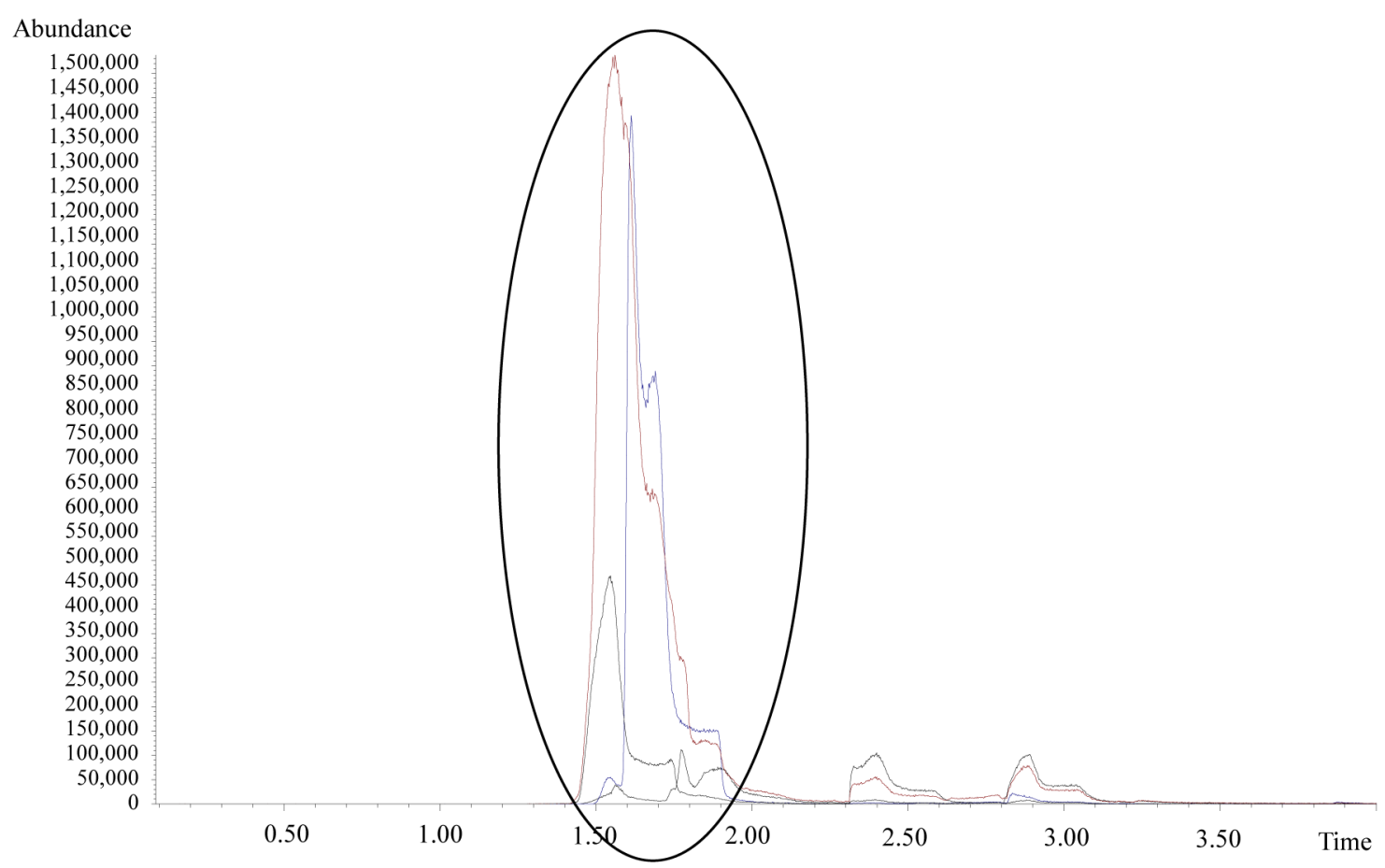

Figure 2. Mass spectrum initial results (up to $3.5 \mathrm{~min}$ ) in fast pyrolysis of 1:1 mixture of Glycerol and ZSM5, at $600^{\circ} \mathrm{C}$.

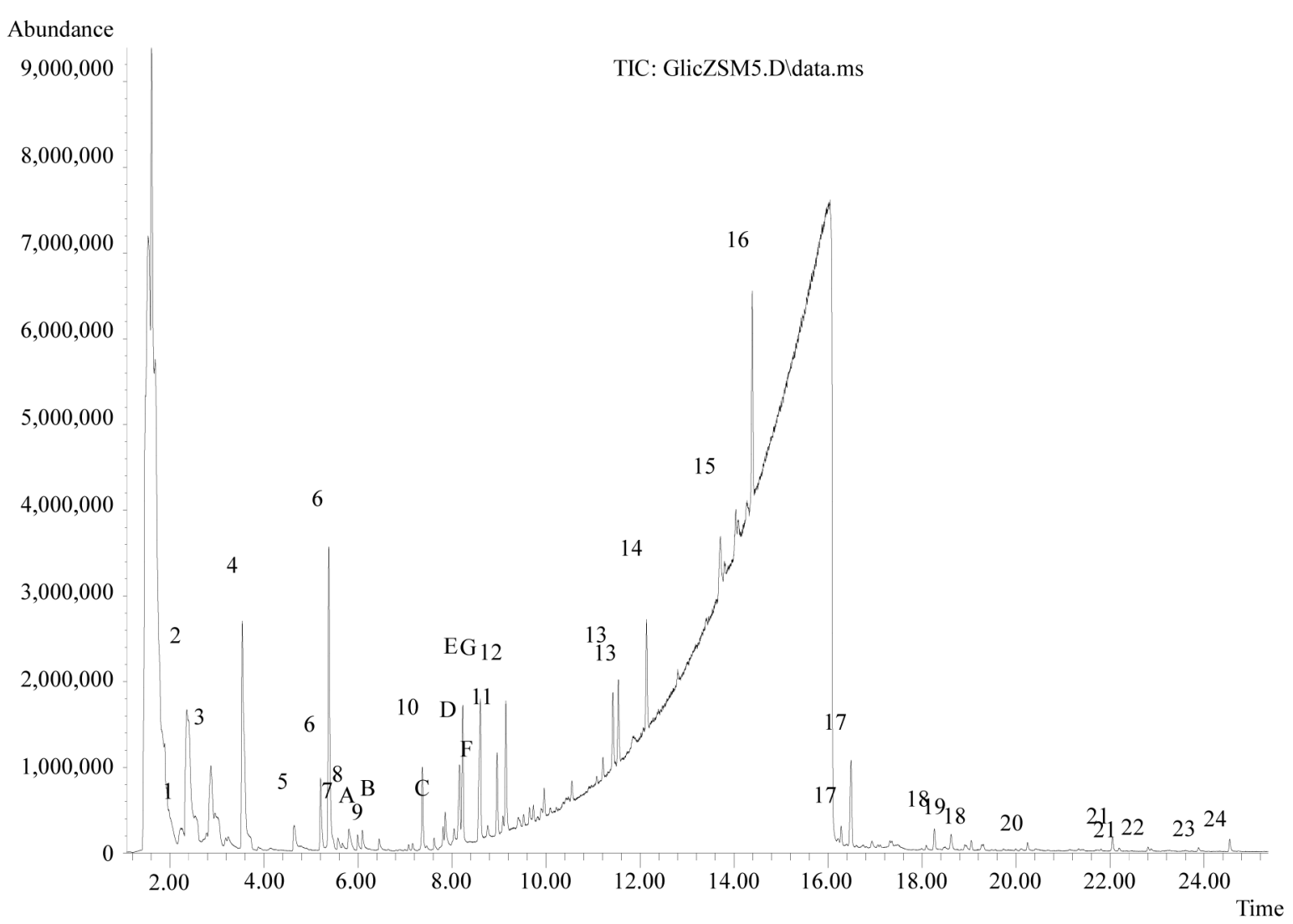

Figure 3. Identification of the GC/MS peaks. 
Table 1. Identification by GC/MS of the glycerol pyrolysis products in the presence of ZSM5.

\begin{tabular}{|c|c|}
\hline Peak number & Substance \\
\hline 1 & Olefins $\mathrm{C}_{6} \mathrm{H}_{8}$ \\
\hline 2 & Benzene; 1-hydroxy 2-propanone \\
\hline 3 & Glycidol $\mathrm{C}_{3} \mathrm{H}_{6} \mathrm{O}_{2}$ \\
\hline 4 & Toluene \\
\hline 5 & 2-cyclopenten 1-one \\
\hline 6 & Ethyl benzene; Xylenes \\
\hline 7 & Olefins $\mathrm{PM}=94$ \\
\hline 8 & Styrene \\
\hline 9 & Methyl 2-cyclopenten 1-one \\
\hline 10 & Alkyl benzene C9 \\
\hline 11 & Indane \\
\hline 12 & Indene \\
\hline 13 & Methyl indenes; Aromatics $\mathrm{C}_{10} \mathrm{H}_{10}$ (PM 130) \\
\hline 14 & Naphthalene \\
\hline 15 & Dimethyl-indene \\
\hline 16 & Methyl-naphthalene \\
\hline 17 & Alkyl-naphthalenes C2 \\
\hline 18 & Alkyl-naphthalenes C3 \\
\hline 19 & Tripropionate of propanetriol $\mathrm{C}_{12} \mathrm{H}_{20} \mathrm{O}_{6}(\mathrm{PM} 260)$ \\
\hline 20 & Fluorene \\
\hline 21 & Methyl fluorenes \\
\hline 22 & Fenantrenes \\
\hline 23 & Dimethyl-fluorenes \\
\hline 24 & Methyl-fenantrenes \\
\hline
\end{tabular}

\section{Acknowledgements}

The authors would like to acknowledge the support and cooperation of the Brazilian Research Council (CNPq), Chemical School of the Federal University of Rio de Janeiro (UFRJ), CENPES-Petrobras Research Center, and Fluminense Federal Institute (IFF).

\section{References}

[1] Biodieselbr (2007) Glycerin Generated in Biodiesel Production: New Uses (Glicerina Gerada na Produção de Biodiesel: Novos Usos). http://www.biodieselbr.com/noticias/biodiesel/glicerina-gerada-producao-biodiesel-novos-usos-29-03-07.htm

[2] Addison, K. (2008) Glycerin. http://journeytoforever.org

[3] Shreeve, R.N. and Brink Jr., J. A. (1980) Chemical Process Industries. 4th Edition, Guanabara Dois, Rio de Janeiro.

[4] Kirk-Othmer Encyclopedia of Chemical Technology (1980) Glycerol. 3rd Edition, Vol. 11, Wiley-Interscience Publications, Chichester. 
[5] May, A., Salvadó, J., Torras, C. and Montané, D. (2010) Catalytic Conversion of Glycerol in Supercritical Water. Chemical Engineering Journal, 160, 751-759. http://dx.doi.org/10.1016/j.cej.2010.04.005

[6] ABIQUIM-Brazilian Chemical Industry Association (2007) Glycerin (Glicerina). Anuário da Indústria Química Brasileira (ABIQUIM), São Paulo.

[7] Quijada-Garrido, I., Iglesias-Gonzalez, V., Mazon-Arechederra, J.M. and Barrales-Rienda, J.M. (2007) The Role Played by the Interactions of Small Molecules with Chitosan and their Transition Temperatures. Glass-Forming Liquids: 1,2,3- Propanetriol (Glycerol). Carbohydrate Polymers, 68, 173-186.

[8] Cortright, R.D. and Dumesic, J. A. (2003) Low-Temperature Hydrocarbon Production Process and Catalysts for the Conversion of Oxygenated Hydrocarbons into Hydrocarbons. US Patent No. 200317017.

[9] Simonetti, D.A., Soares, R. and Dumesic, J.A. (2006) Glycerol as a Source for Fuels and Chemicals by Low-Temperature Catalytic Processing. Proceedings of the American Chemical Society National Meeting, San Francisco, 10-14 September 2006, 223.

[10] Cortright, R.D. and Dumesic, J.A. (2003) Hydrogen Production from Oxygenated Hydrocarbons by Vapor and Condensed Liquid-Phase Reforming for Fuel Cell Use. US Patent No. 20040022723.

[11] Morrison, R. and Boyd, R. (1978) Organic Chemistry. 6th Edition, Calouste Gulbenkian Foundation, Lisbon.

[12] Allinger, N. (1979) Organic Chemistry. 2nd Edition, Livros Técnicos e Científicos, Rio de Janeiro.

[13] Morita, T. and Assumpção, R.M.V. (1976) Manual of Solutions, Reactants and Solvents. Standardization, Preparation, Purification (Manual de Soluções, Reagentes e Solventes. Padronização, Preparação, Purificação). 2nd Edition, Edgard Blucher, São Paulo.

[14] Schrauth, W. (1925) Manuel pour la Fabrication des Savons. 5th Edition, Paris et Liège, Paris.

[15] Carmines, E.L. and Gaworski, C.L. (2005) Toxicological Evaluation of Glycerin as a Cigarette Ingredient. Food and Chemical Toxicology, 43, 1521-1539. http://dx.doi.org/10.1016/j.fct.2005.04.010

[16] Mota, C.J.A., Silva, C.X.A. and Gonçalves, V.L.C. (2009) Glicerochemistry: New Products and Processes for the Glycerol from Biodiesel (Gliceroquímica: Novos Produtos e Processos para o Glycerol do Biodiesel). http://www.scielo.br/pdf/qn/v32n3/a08v32n3.pdf

[17] Kim, Y.T., Jung, K.-D. and Park, E.D. (2011) Gas-Phase Dehydration of Glycerol over Silica-Alumina Catalysts. Applied Catalysis B: Environmental, 107, 177-187. http://dx.doi.org/10.1016/j.apcatb.2011.07.011

[18] Suprum, W., Laeser, R. and Papp, H. (2011) Reaction Pathways of Catalytic Gas Phase Oxidation of Glycerol over Mixed Metal Oxides. Proceedings of the Conference Catalysis: Innovative Applications in Petrochemistry and Refining, Dresden, 4-6 October 2011, 253-260.

[19] Suprum, W., Lutecki, M. and Papp, H. (2011) TPD-TG-MS Investigations of the Catalytic Conversion of Glycerol over $\mathrm{MO}_{\mathrm{x}}-\mathrm{Al}_{2} \mathrm{O}_{3}-\mathrm{PO}_{4}$ Catalysts. Chemical Engineer Technology, 34, 134-139. http://dx.doi.org/10.1002/ceat.201000316

[20] Castelló, M.L., Dweck, J. and Aranda, D.A.G. (2009) Thermal Stability and Water Content Determination of Glycerol by Thermogravimetry. Journal of Thermal Analysis and Calorimetry, 97, 627-630.

[21] Castelló, M.L., Dweck, J. and Aranda, D.A.G. (2011) Kinetic Study of Thermal Processing of Glycerol by Thermogravimetry. Journal of Thermal Analysis and Calorimetry, 105, 737-746.

[22] Luz, A.B. (1994) Zeolits: Properties and Industrial Uses (Zeólitas: Propriedades e Usos Industriais). In: Mineral Technology (Tecnologia Mineral), Vol. 68, CETEM/CNPq, Rio de Janeiro.

[23] Olson, D.H., Tokotailo, G.T. and Lawton, S.L. (1981) Crystal Structure and Structure Related Properties of ZSM-5. Journal of Physical Chemistry, 85, 2238-2243. 